\title{
The Çevre Kale fortress and the outer enclosure on the Karacadağ at Yaraşlı
}

N. Pınar Özguner and Geoffrey D. Summers

\section{CpenEdition}

\section{Journals}

\section{Electronic version}

URL: http://journals.openedition.org/anatoliaantiqua/432

DOI: 10.4000/anatoliaantiqua.432

\section{Publisher}

IFEA

Printed version

Date of publication: 1 May 2017

Number of pages: 1-16

ISBN: 978-2-36245-066-2

ISSN: 1018-1946

\section{Electronic reference}

N. Pınar Özguner and Geoffrey D. Summers, "The Cevre Kale fortress and the outer enclosure on the Karacadağ at Yaraşlı », Anatolia Antiqua [Online], XXV | 2017, Online since 01 May 2019, connection on 19 December 2020. URL : http://journals.openedition.org/anatoliaantiqua/432 ; DOI : https://doi.org/ 10.4000/anatoliaantiqua.432 


\section{ANATOLIA ANTIQUA ESKI ANADOLU}

\section{XXV}

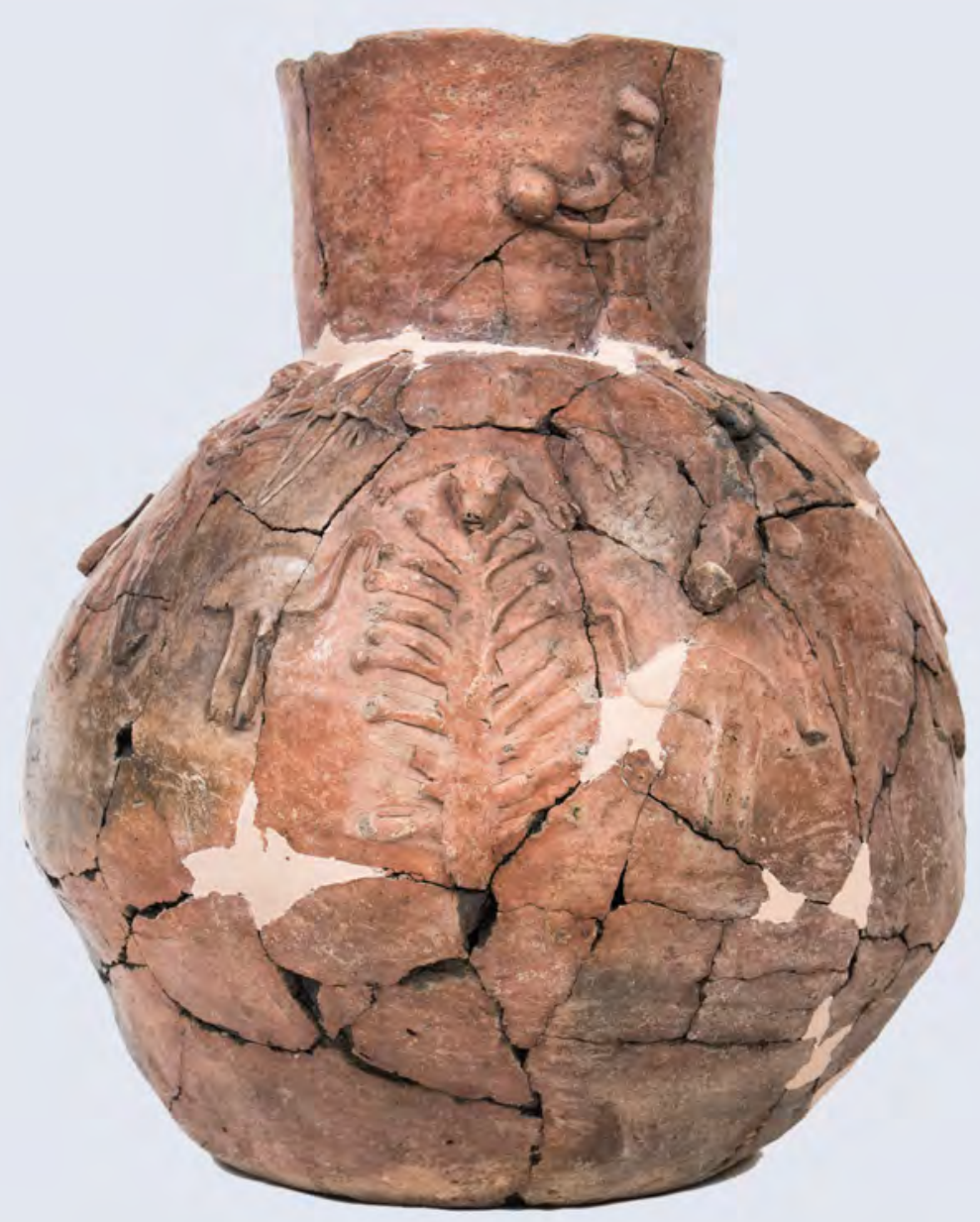

INSTITUT FRANÇAIS D'ETUDES ANATOLIENNES GEORGES-DUMEZIL

CNRS USR 3131

DE BOCCARD 


\section{TABLE DES MATIERES}

N. Pınar ÖZGÜNER et Geoffrey D. SUMMERS

The Çevre Kale Fortress and the outer enclosure on the Karacadağ at Yaraşl1

Abuzer KIZIL et Asil YAMAN

A group of transport amphorae from the territorium of Ceramus: Typological observations

Tülin TAN

The hellenistic tumulus of Eşenköy in NW Turkey

Emre TAŞTEMÜR

Glass pendants in Tekirdağ and Edirne Museums

Liviu Mihail IANCU

Self-mutilation, multiculturalism and hybridity. Herodotos on the Karians in Egypt (Hdt. 2.61.2) .....

\section{CHRONIQUES DES TRAVAUX ARCHEOLOGIQUES EN TURQUIE 2016}

Erhan BIÇAKÇI, Martin GODON et Ali Metin BÜYÜKKARAKAYA, Korhan ERTURAÇ, Catherine KUZUCUOĞLU, Yasin Gökhan ÇAKAN, Alice VINET

Les fouilles de Tepecik-Çiftlik et les activités du programme Melendiz préhistorique, campagne 2016

Çiğdem MANER

Preliminary report on the forth season of the Konya-Ereğli Survey (KEYAR) 2016

Sami PATACI et Ergün LAFLI

Field surveys in Ardahan in 2016

Erkan KONYAR, Bülent GENÇ, Can AVCI et Armağan TAN

The Van Tušpa Excavations 2015-2016

Martin SEYER, Alexandra DOLEA, Kathrin KUGLER, Helmut BRÜCKNER et Friederike STOCK The excavation at Limyra/Lycia 2016: Preliminary report

Abuzer KIZIL, Koray KONUK, Sönmez ALEMDAR, Laurent CAPDETREY, Raymond DESCAT, Didier LAROCHE, Enora LE QUERE, Francis PROST et Baptiste VERGNAUD

Eurômos : rapport préliminaire sur les travaux réalisés en 2016

O. HENRY et D. LÖWENBORG, Fr. MARCHAND-BEAULIEU, G. TUCKER, A. FREJMAN,

A. LAMESA, Chr. BOST, B. VERGNAUD, I. STOJANOVITC, N. CARLESS-UNWINN,

N. SCHIBILLE, Ö.D. ÇAKMAKLI, E. ANDERSSON

Labraunda 2016 


\section{N. Pınar ÖZGÜNER* and Geoffrey D. SUMMERS** \\ THE ÇEVRE KALE FORTRESS AND THE OUTER ENCLOSURE ON THE KARACADAĞ AT YARAŞLI}

In 1992 an aerial survey of the Iron Age fortress of Çevre Kale was made using a tethered heliumfilled blimp. This fortress is located on the slopes of the Karacadag above the large village of Yaraşlı, close to the northeast corner of Tuz Gölü, the Salt Lake (Fig. 1) ${ }^{1}$. That brief survey was focussed on the highly visible fortress together with the obvious traces of extra mural settlement that lay immediately to the southwest. At that time the southwestern stretch of the huge, $11 \mathrm{~km}$ long, walled, outer enclosure that stretches up to the summit of the Karacadağ was looked at only in passing, neither its date nor its significance being properly understood. The existence of this outer enclosure had been noted previously by Stephen Mitchell, although he did not provide a description ${ }^{2}$.

During a visit to the site with students in 2000 the north side of the enclosure wall was observed, against the background of snow, following a course along the topographic divide of the northern ridge. On that occasion inclement weather only permitted casual investigation of a short stretch of the wall ascending towards the summit, but that in itself was sufficient for the scale and importance of the enclosure to be recognised. Subsequent visits established that the course of the wall did indeed extend to the mountain summit and, furthermore, that it descended down to the edge of Yaraşli village along the west ridge of the Karacadağ. This stretch of the wall from the mountain peak to the village is shown as a road or track on the 1:25,000 map that was drawn from stereo pairs of aerial photographs by the Directorate of Mapping (Fig. 2).
In 2004, when Özgüner was searching for a site on which to base her MSc thesis that would explore the potentials of high altitude declassified aerial photography in the archaeology of Anatolia, a reexamination of Çevre Kale to now include the enclosure and other previously unobserved features was an obvious candidate. This paper reports on the main outcomes of that study, although subsequent developments in the application of GIS to archaeology have made redundant detailed description of the innovative methods developed by Özgüner for her thesis ${ }^{3}$. The ensuing ten years have also seen great improvements in the resolution of satellite imagery provided by Google Earth as well as advances in the tools provided by Google Earth Pro. As a result of these developments and their free public availability the data sets of maps and aerial photographs used in the earlier study are now largely superseded. They do, however, retain the potential to document ancient features that have since been damaged or destroyed by looting, mechanized agriculture, expanding modern settlements, and so forth. The present paper draws heavily on Özgüner's written descriptions and photographs taken on the ground, but Google Earth imagery has largely replaced balloon and aeroplane borne photography as well as printed maps. Annotated Google Earth images are reproduced here in greyscale on the assumption that the reader will have online access to Google Earth. Any future study would doubtless employ a drone for aerial mapping in combination with geophysical survey to document sub-surface features, perhaps with real-time integrative software ${ }^{4}$. The

*) N. Pınar Özgüner, Gaziantep Üniversitesi, Fen-Edebiyat Fakültesi, Arkeoloji Bölümü: pinar.ozguner@gmail.com

**) Geoffrey D. Summers, Research Associate, Oriental Institute, University of Chicago: summersgd@gmail.com

1) Summers 1992.

2) The dimensions given in Mitchell 1973 relate to the enclosure wall rather than the fortress (contra Summers 1992: 183). Mitchell appears to have been the first scholar to have noted the outer enclosure. Mellaart 1983 provided the first detailed, if not wholly accurate, description of the fortress. For discussion of Mellaart's account and other previous research see Summers 1992: 180-183. Strobel 2008, unaware of Özgüner's work, adds little of relevance.

3) Özgüner 2006.

4) For example, Roosevelt 2014; Roosevelt et al. 2015. 


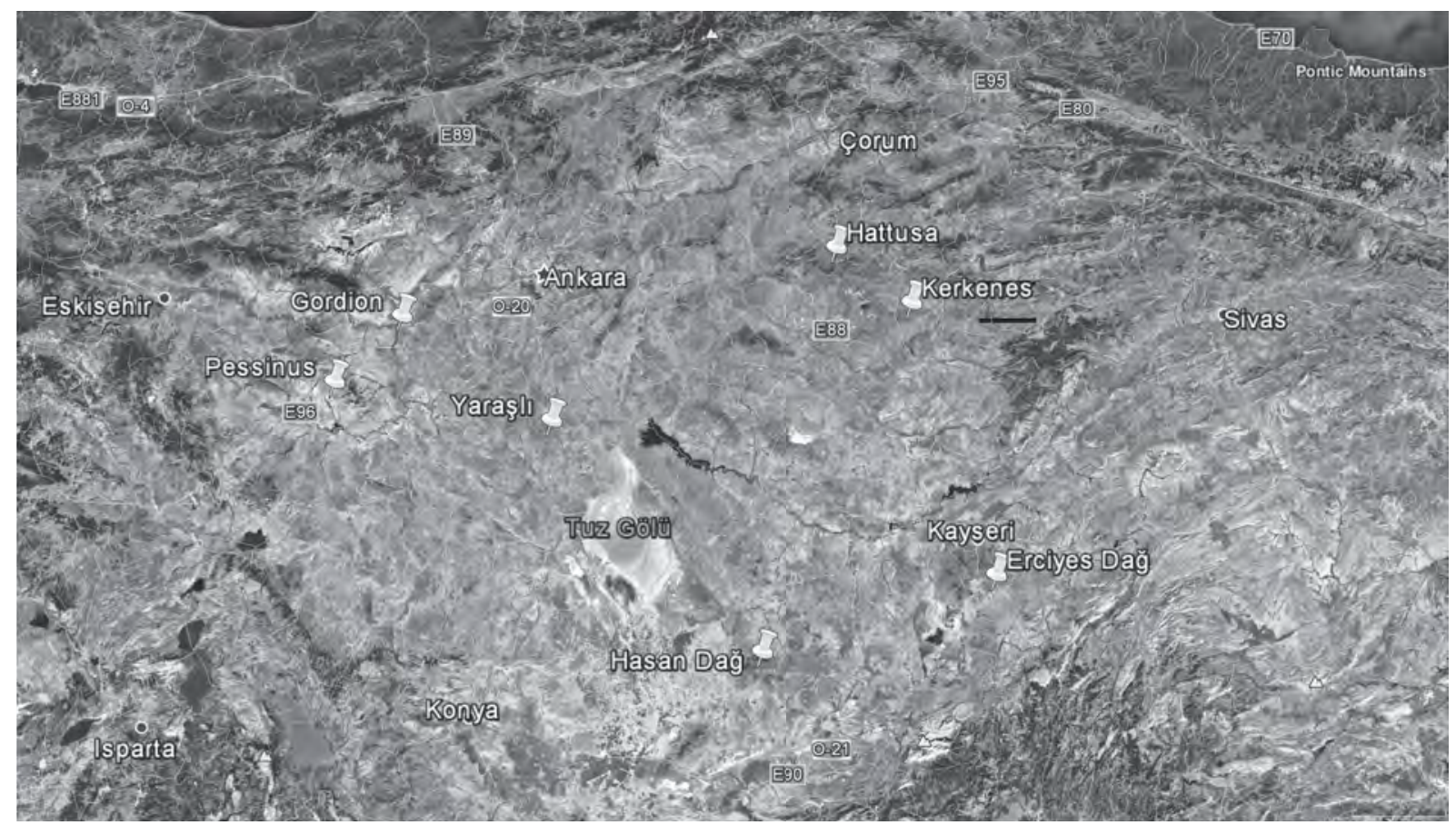

Fig. 1 : Google Earth image showing the location of Yaraşlı, northeast of Tuz Gölü and south of Ankara, with the bend of the Kizılırmak to the east.

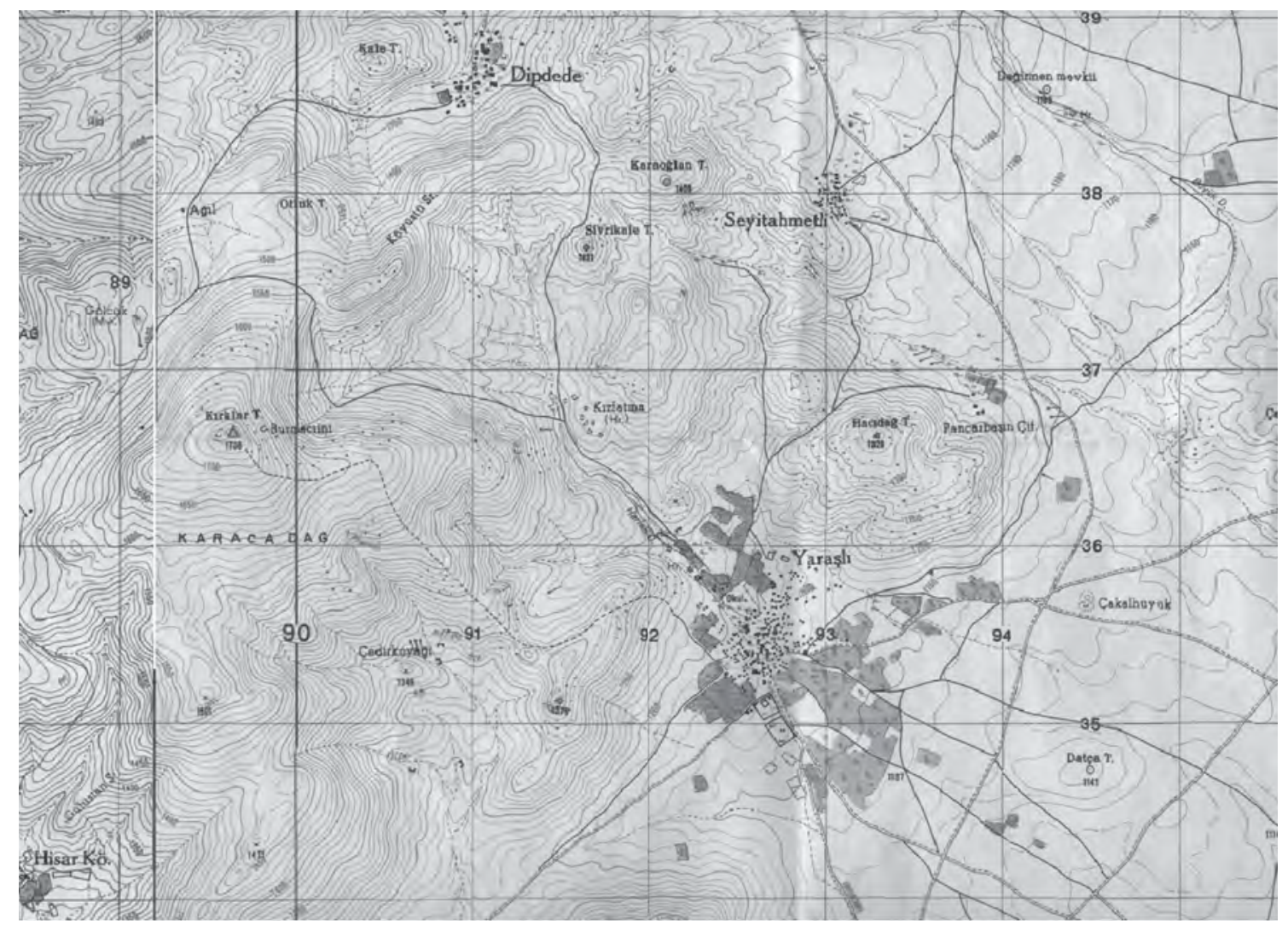

Fig. 2 : A portion of the 1:2500 map showing the study area, not to scale. 
focus of this paper is the Iron Age enclosure not previously described.

\section{THE STUDY AREA}

The Karacadag is a volcanic mountain mainly composed of andesitic-dacitic lavas ${ }^{5}$. It is located approximately $85 \mathrm{~km}$ south of Ankara and $22 \mathrm{~km}$ west-southwest of the northern tip of the Tuz Gölü, or Salt Lake (Fig. 1-2). Its peak, Kirklar Tepe, attains an altitude of approximately $1,740 \mathrm{~m}$ above sea level (Fig. 3-4). Co-ordinates of the summit, where there are communication masts, are $39^{\circ} 11^{\prime} 6.94$ 'N , 32 53 '20.34'E. The mountain dominates the surrounding landscape and can be seen from afar, with the peak of Hasan Dağ, $160 \mathrm{~km}$ to the southeast generally visible. Anderson plausibly suggested that this peak was the site of the $9^{\text {th }}$ century A.D. Icamos Beacon, one in a chain of nine signal fires used to telegraph between the Cilician Gates and Constantinople devised by Leo the Mathematician during the Byzantine-Arab wars ${ }^{6}$. Although no evidence for this beacon is visible on the ground, an undated and now plundered cemetery, presumably indicated by the name Burmaciini on the 1:25,000 map (Fig. 2), in addition to considerable recent disturbance associated with the installation of communication masts, could have obscured or obliterated any traces that there might once have been. The next beacon to the southeast is generally thought to have been on Hasan Dağ, but the location of that to the northwest is more problematic. Anderson, perhaps correctly, suggested Mount Dindymos, identified with Günyüzü Dağ, near Pessinus? ${ }^{7}$.

The Karacadağ dominates the surrounding area and affords vantage points for surveillance of both ancient and modern routes. The eastern slopes of the mountain, including Çevre Kale, are visible from main route between Ankara and the Cilician Gates, known in Roman times as the Pilgrim's $\mathrm{Road}^{8}$. More important, perhaps, were routes to the northwest passing to the north of the Karacadag and leading to Gordion and Pessinus that were doubtless in use during the Bronze Age 9 . However, the orientation of the Çevre Kale gate together with the absence of a north gate in the outer enclosure wall undoubtedly demonstrates that the main approach to the site was from the southwest. It can thus be concluded that the main purpose of the fortress was connected with passage between the northern end of the Tuz Gölü and the Karacadağ, and thus with the route that traversed the Cihanbeyli plateau in the direction of Konya.

The site comprises several elements. Of these the most important is the Iron Age fortress of Çevre Kale that was the subject of the original study (Fig. 5-6). Not previously described is a large enclosure that was almost certainly contemporaneous with the fortress. This enclosure is demarcated by a stone circuit wall some $11 \mathrm{~km}$ in length stretching from the peak of the Karacadag on one side to the flat-topped hill called Hacidag Tepe, located to the east of the fortress, on the other. Within the circuit of this enclosure, immediately outside the fortress, is an Iron Age settlement, called the Outer Town in the 1992 report. Also not recognised at the time of the original survey is a large, flat, Old Hittite, settlement situated on gently sloping ground to the north of the fortress, very largely or completely with the boundaries of the Iron Age enclosure. No study of this area has been made, only cursory observations during a brief visit. While no pottery has been collected or recorded, perusal of sherds in the plough-soil leave no doubt as to the Old Hittite date of the main period of occupation.

When the 1992 survey was conducted this area had not recently been ploughed, although traces of old field boundaries can be seen ${ }^{10}$. Remains dating from Hellenistic to Byzantine times lie beneath and in the vicinity of Yaraşlı village, including the small, steep sided outcrop of volcanic rock called Yarașl1 Kale where there is a scatter of sherds but no substantial foundations and only the slightest traces of possible defences. There are rockcut tombs of Roman or Byzantine date in the sides of the valley to the northeast of the village, and inscribed Byzantine gravestones built into a village çeşme ${ }^{11}$. There is a

5) Kurt, Asan and Ruffet 2008

6) Anderson 1899 .

7) Anderson 1899: 115. For references to later studies see Haldon 1990: 254-56, (C) 618-630; we are grateful to Nikos Tsivikis for bringing this to our attention.

8) French 1981

9) For the second millennium see contributions to Weeden and Ullmann, 2017

10) The permit issued by General Directorate for the balloon survey specifically excluded the collection of any material. At that time the Konya Museum had agreed to the survey on condition that no finds would be brought to the Museum.

11) http://mama.csad.ox.ac.uk/monuments/browse-Yara\%C5\%9Fl\%C4\%B1.html 


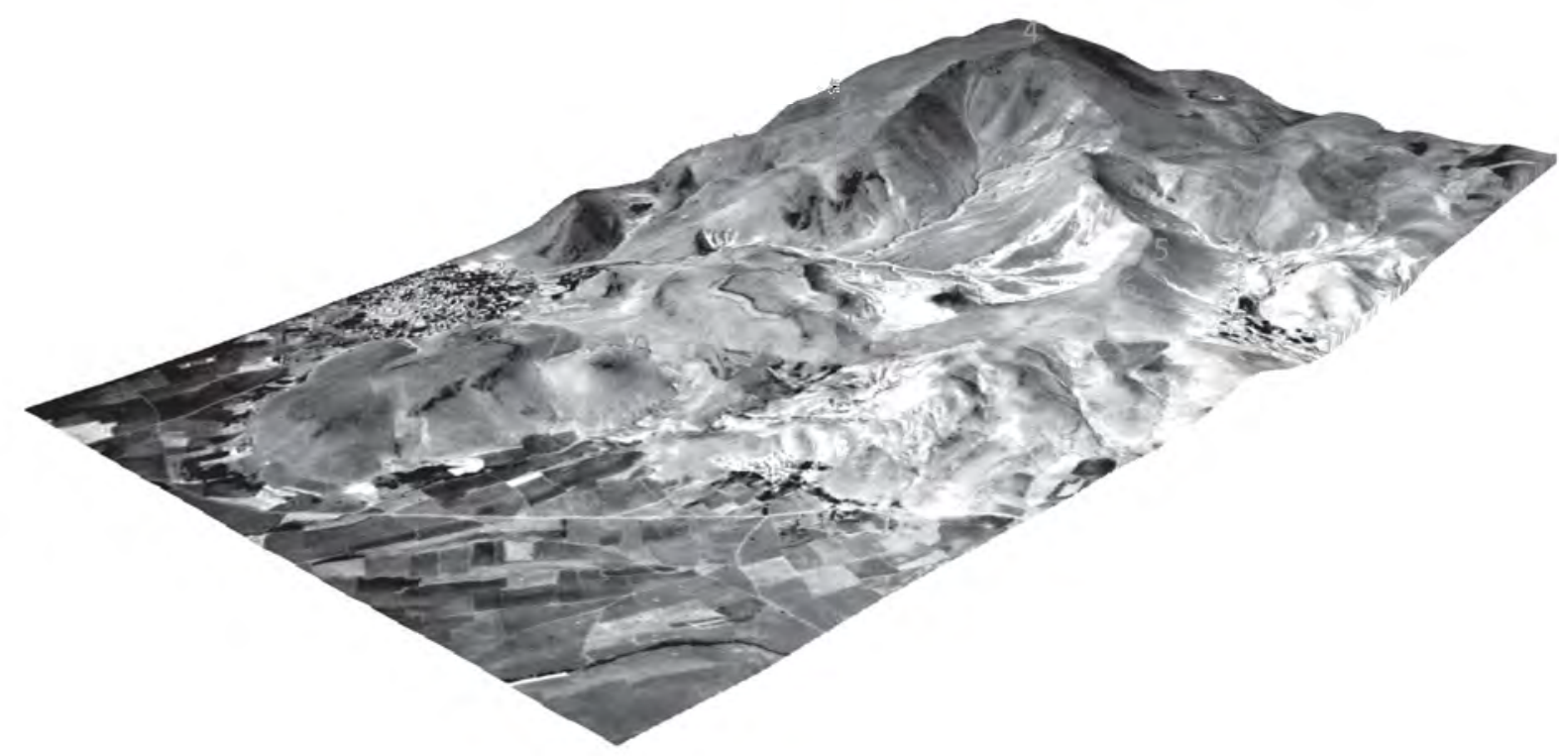

Fig. 3 : Digital Terrain Model (DTM) combined with rectified ortho-photos using TNTmips V6.0.

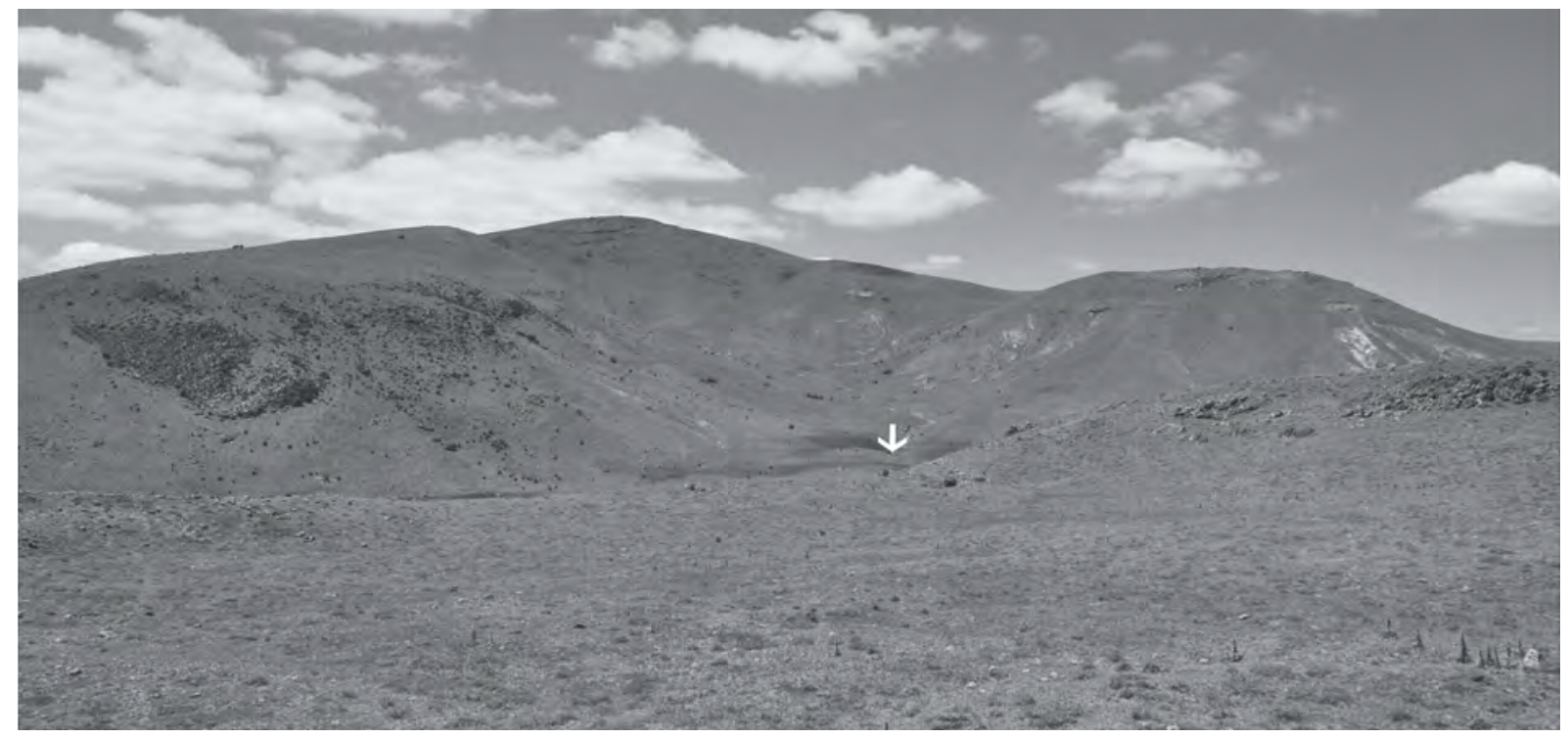

Fig. 4 : Kırklar Tepe, the peak of Karacadağ, from the top of the east rampart of Çevre Kale. The southwest kale rampart runs across the image with the gate below the arrow and the southwest bastion to the right.

substantial Byzantine settlement obscured beneath the village of Yaraşl1, which is rapidly growing into a modern town. Additionally, there are traces of Byzantine occupation on Hacidağ Tepe on the northeastern side of Yaraşlı village. Yaraşlı might, as originally suggested by Anderson, be a better candidate for identification with the small Roman and Byzantine town of Kinna than Karahamzal1 ${ }^{12}$.

Of other sites on the slopes of the Karacadag covered by the aerial survey the most prominent is a small conical hill on the truncated top of which is a small kale with clearly visible white mortared walls

12) http://mama.csad.ox.ac.uk/monuments/kinna.html\#\%C3\%87evre\%20Kale

http://mama.csad.ox.ac.uk/monuments/MAMA-XI-234.html.

Anderson 1899: 115. Crowfoot 1899: map on pl. IV followed this identification.

See also Mitchell 1993, I, p. 67 with n. 56 and p. 96; Mitchel 1982: 21-22 and 396. It is not impossible that the inscribed Roman statue and other spolia found at Karahamzalı had been moved. 


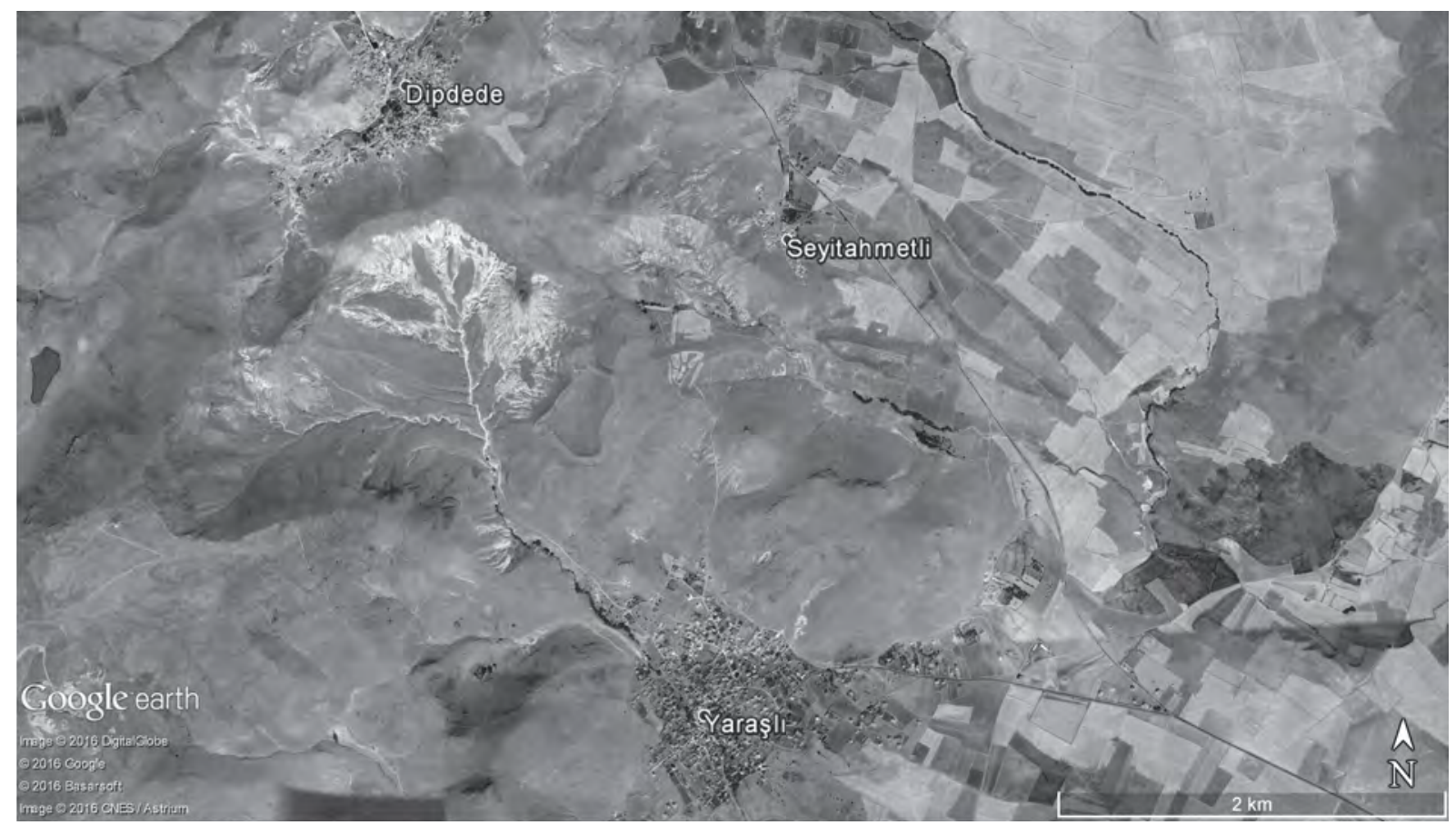

Fig. 5 : Google Earth image of the study area.

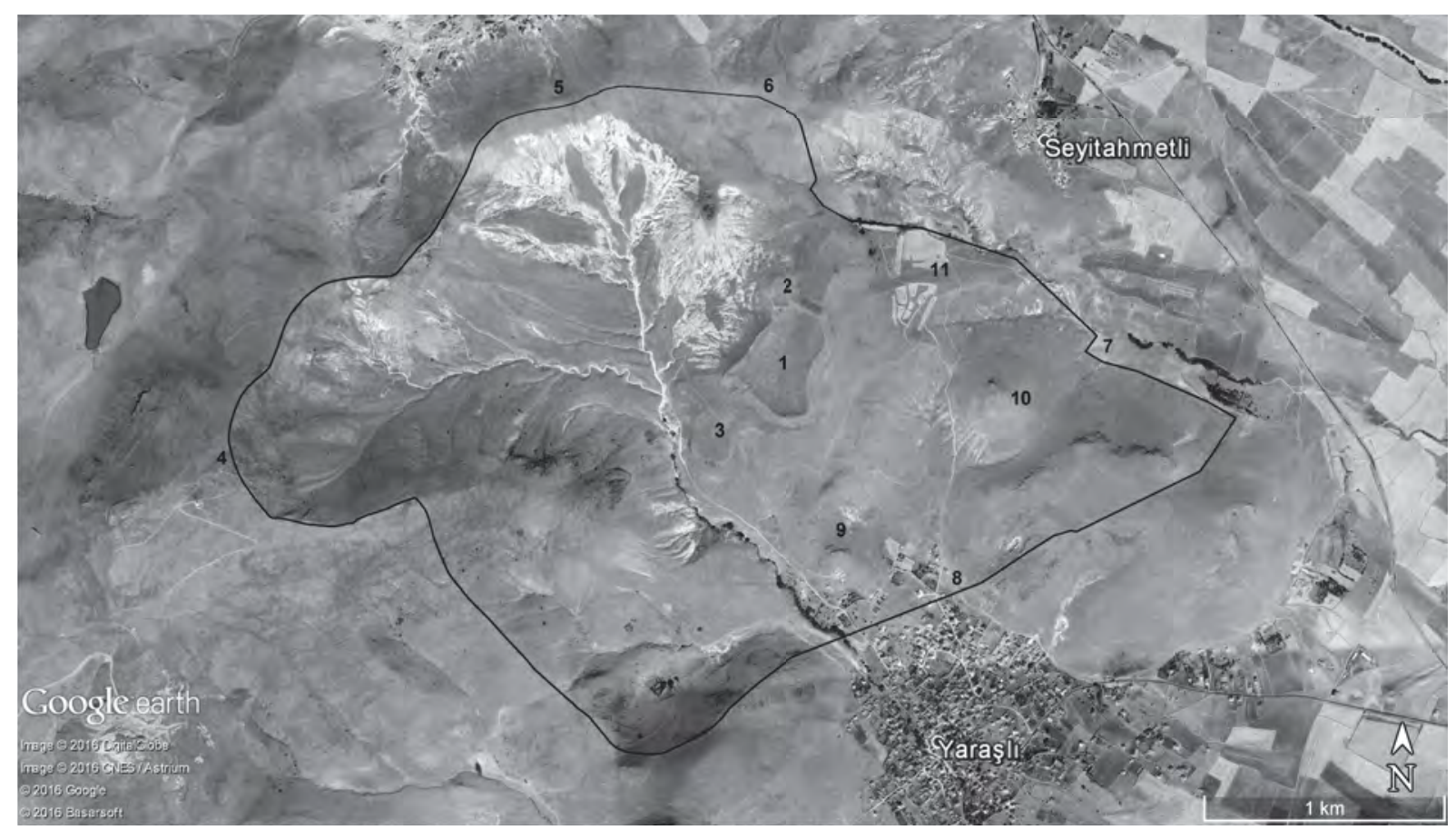

Fig. 6 : Goole Earth image showing the enclosure wall: 1. Çevre Kale; 2. kale citadel; 3. Iron Age settlement; 4. Kırklar Tepe; 5. Köyüstü Sırtı; 6. Karaoğlan Tepe; 7. gate in the east side; 8. dam; 9. Yaraşlı Kale; 10. Hacıdağ Tepe; 11. area of second millennium settlement. 
and towers indicative of a Byzantine or later date. Marked as Kale Tepe on the 1:250,000 scale map, this site is located on the west side of Dipdede village and some $4 \mathrm{~km}$ north of Çevre Kale (Fig. 2, 5 and 16). It has not been visited. To avoid repetition no mention of other sites in the vicinity of Yaraşlı reported in the 1992 paper is made here.

With regard to the past environment, the aspect of the Karacadag and its environs in the Middle Iron Age was probably not very different from that of today. While water levels in the permanent lakes Tuz Gölü and Kulu Gölü, as well as seasonal wetlands such as Kurak Göl, situated in the saddle of the westernmost range of Karacada $\breve{g}$, fluctuate from year to year, these changes did not impact on the elevated sites described here. It is doubtful, furthermore, that these fluctuations would have affected the main lines of communication. There is no reason to think that the area was substantially more forested in the first millennium B.C. than it is today. ${ }^{13}$

Administratively the site lies in Konya Province, within the District of Kulu. Formerly however, until 1957, it formed part of the Haymana District of Ankara Province. The main approach to the site is and always was from the direction of Yaraşlı village to the south from which a vehicular track ran up to the only gateway in the massive defences of the fortress. Although the smaller villages of Dipdede to the north and Seyitahmetli to the northeast are both closer (Fig. 2), access from them is more difficult.

\section{ÇEVRE KALE}

The fortress, constructed on a flat eastern spur of the Karacadağ where it is visible from the AnkaraAdana highway, lies more or less in the centre of the enclosure (Fig. 6). Here it is not necessary to do more that summarise the description given in the 1992 report $^{14}$, with the caveat that the term fortress is now preferred over the terms upper town and citadel previously employed. Located on fairly level terrain that falls away steeply on all sides the fortress comprises two elements, a flat-topped citadel at the north end and the main fortified area (Fig. 8-11). Both are surrounded by a massive rampart supporting a defensive wall with abutting towers and buttresses. The preserved stone base of the circuit wall is some 3.5 to $4.5 \mathrm{~m}$ in width. There are towers and buttresses at irregular intervals that butt against the outer face of the wall.

The inner face of the southeastern section of the rampart is composed of very loose stone. Here, within the rubble and parallel with the rampart are stretches of stone walling that provided the stability necessary to maintain the steep inclination. Similar parallel walls, probably serving the same function but where the material of which the rampart was composed was soil rather than stone, occur on the eastern side of the citadel.

Outside, at the base of the rampart, a ditch surrounds all but the north-west side of the citadel and fortress where the natural slope descends to a lower elevation than elsewhere and the rampart is very largely a natural rock ridge (Fig. 10 and 11). A single strong gate pierces the southwest stretch of rampart and wall. This gate was heavily robbed of stone to build the Yaraşl1 school some years before the 1993 survey. As a result it is not possible to discern the gate plan without excavation, but it is likely that there was a large external chamber on the southeast side, and that it was strengthened with outworks. The inner portion of the gate passage was steeply inclined.

It is probable that the steep slopes of the largely natural citadel at the north end of the fortress were continuous with the main ramparts, as indicated by the walls on the east side of the citadel. In this regard it is noted that what might have been a passage of some kind between the main section of fortress rampart and the western side of the citadel is a secondary, and perhaps not very ancient, feature the likely purpose of which was to facilitate the movement of flocks and herds (Fig. 11). Today there is no source of water within the ramparts, but this may not always have been so and there are features just inside the gate that might have been connected with water storage.

Since the 1992 report was written it has become evident that the massive rampart and associated features are Middle Iron Age in date. The rampart core is largely composed of material taken from the second millennium, Old Hittite period, settlement to the north east of the fortress (see below), but this material does not date the construction of the rampart. Neither the rampart nor the stone base of the circuit wall that it supports are second millennium in date, while the collapsed postern gate that Mellaart thought

13) For reconstruction of the climate see Kuzucuoğlu 2015.

14) Summers 1992, further details and illustrations will be found in Özgüner 2006. 


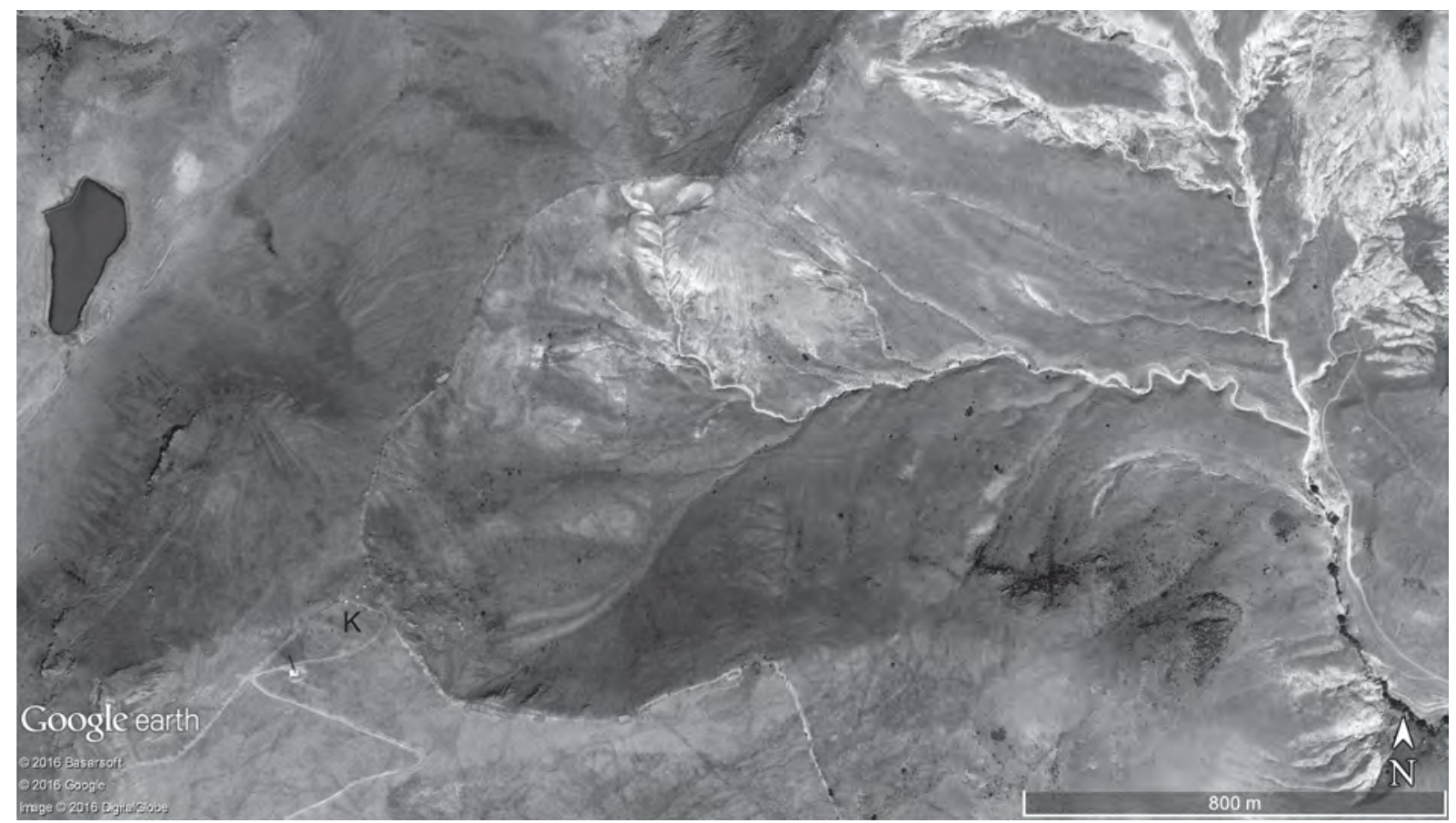

Fig. 7 : On this Google Earth image the enclosure wall runs north from bottom centre before turning west along the ridge and curving northwest to the Kurklar Tepe, marked K.

The continuation snakes its way northeastwards to exit the image at centre top.

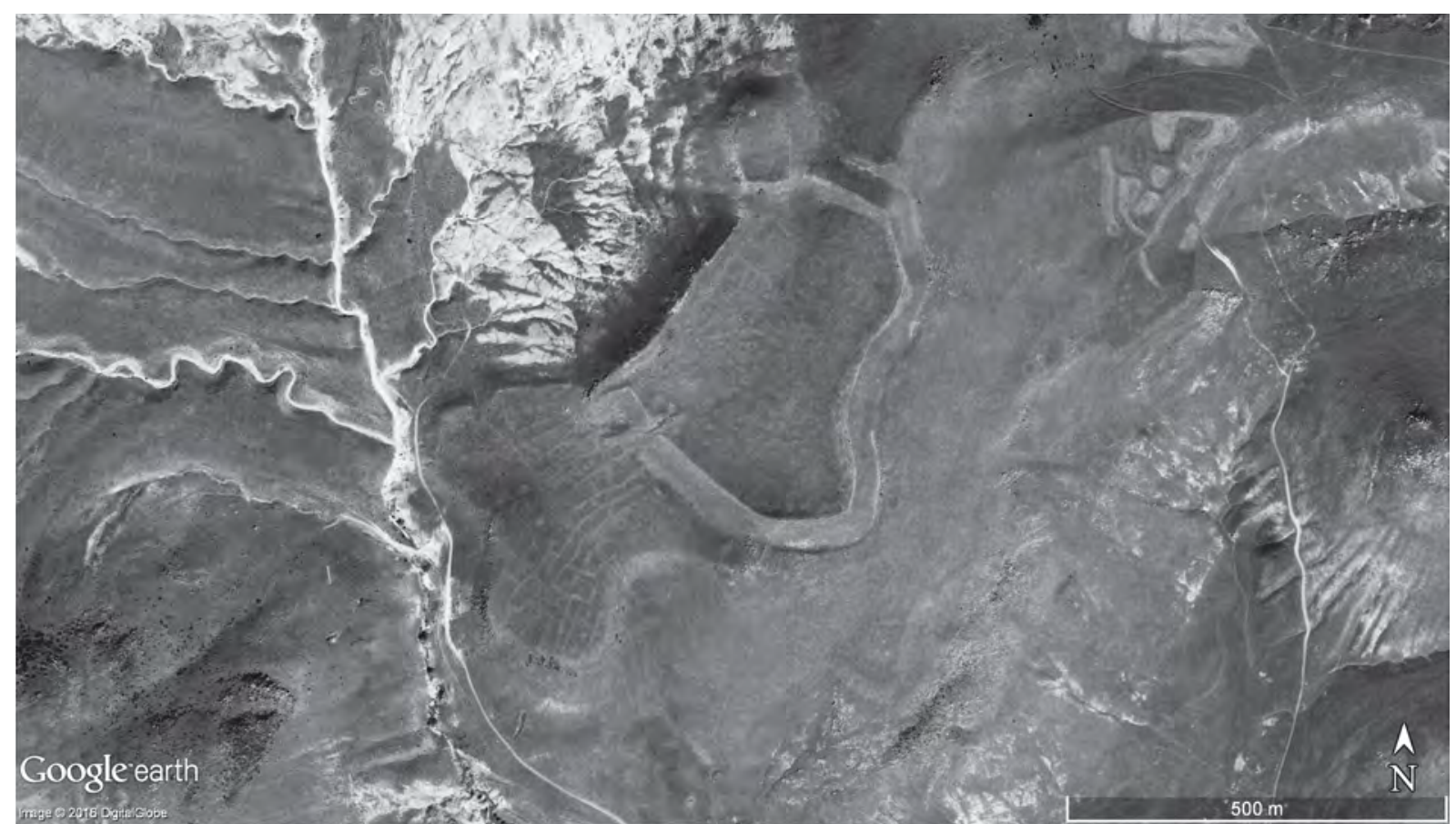

Fig. 8 : Using the historical imagery tool in Google earth permits selection from a variety of imagery taken under different conditions at different times. Çevre Kale, at centre, with citadel at top, and the Iron Age settlement to the southwest between the kale ramparts and the edge of the bluff, stand out particularly well. 


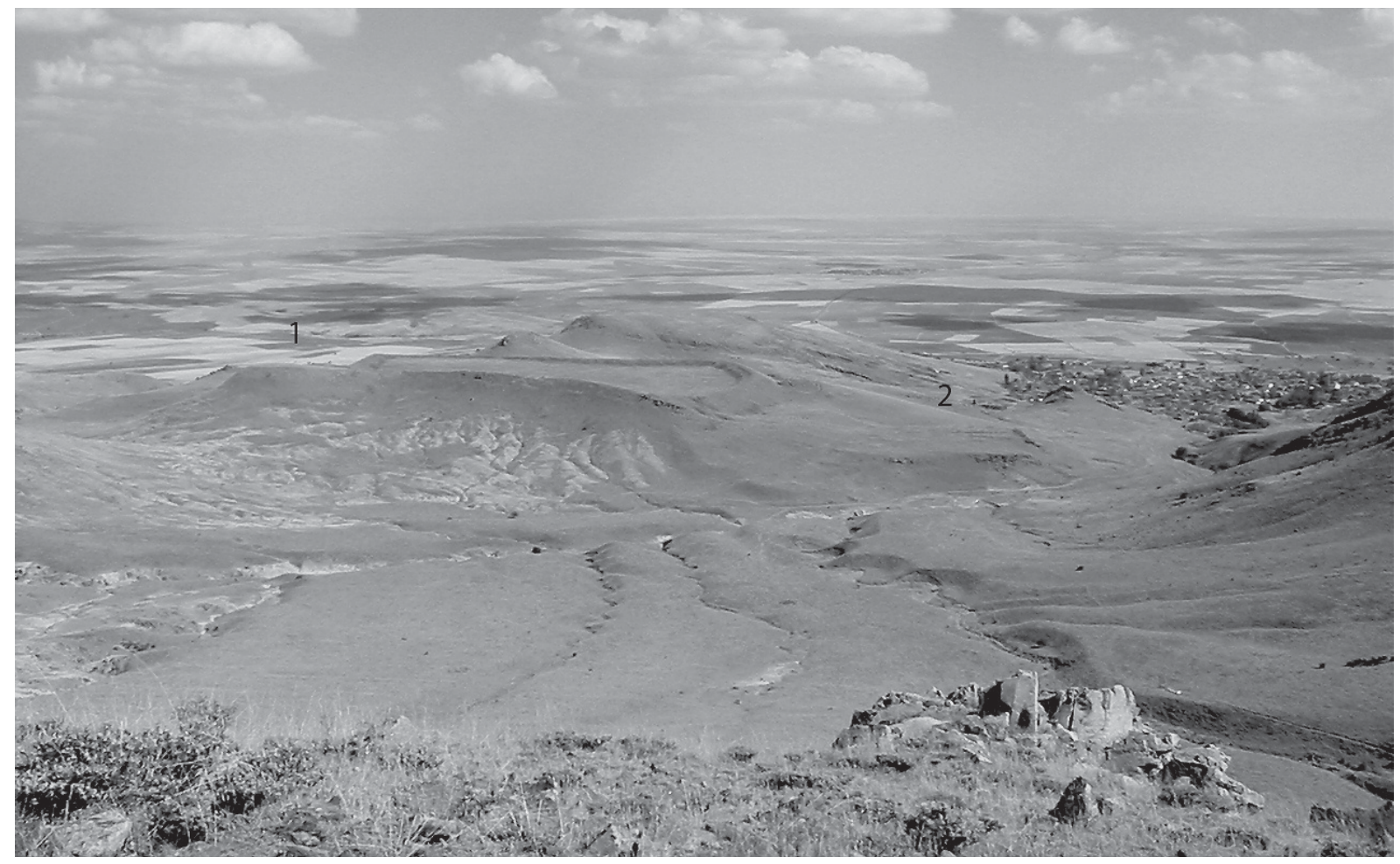

Fig. 9 : Çevre Kale from Kırklar Tepe. The citadel is below 1, the lower Iron Age settlement below 2 , Yaraşlı village at right.

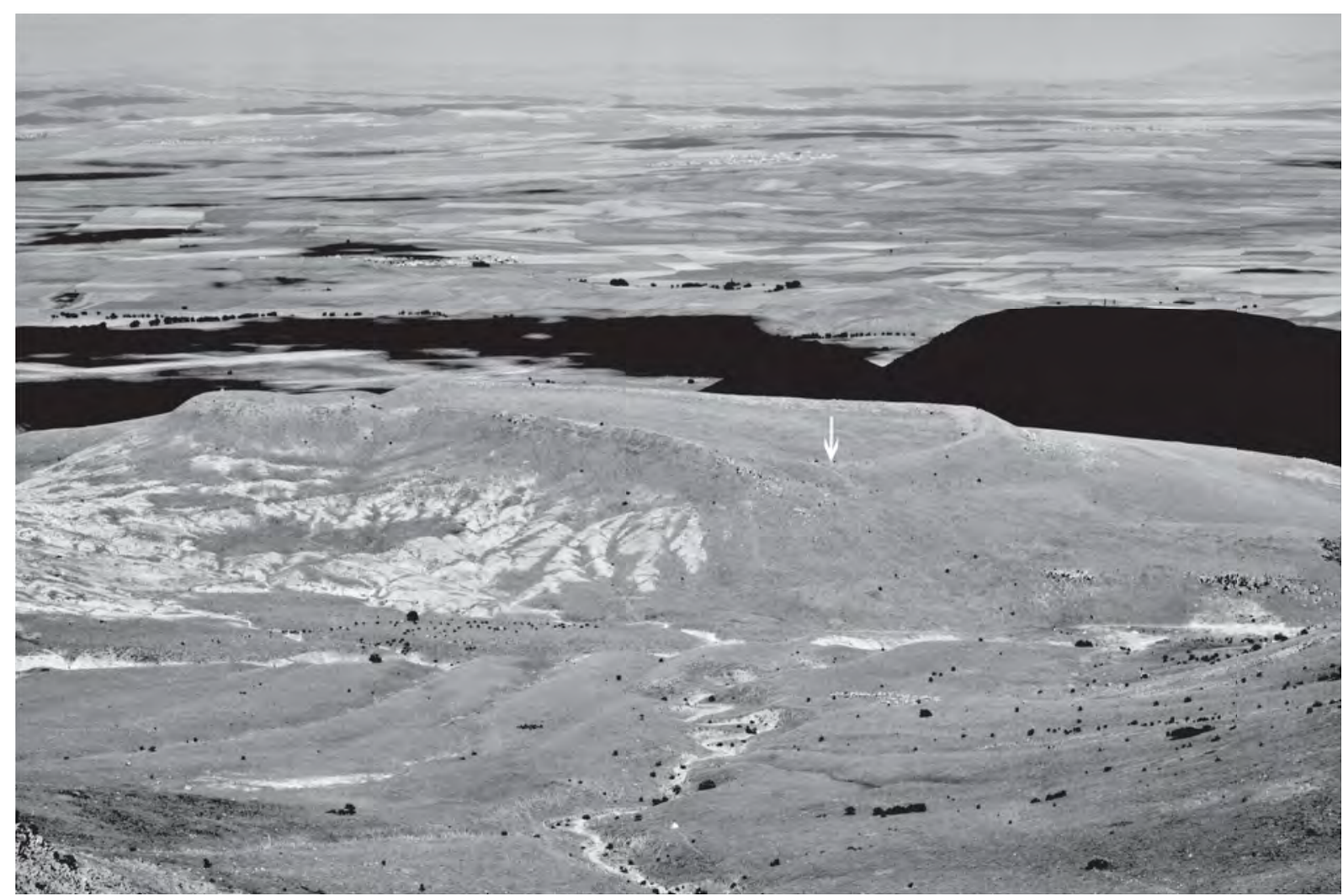

Fig. 10 : Çevre Kale from the slopes of the Karacadağ. The ramparts are clearly seen, the citadel at left, the gate below the arrow, and the lower outer settlement at right. The southwest rampart incorporates a natural ridge of rock that attains the greatest elevation in the entire circuit. 
he might be able to discern does not in fact exist. Whether the circuit wall was built entirely of stone, like the city wall at Kerkenes Dağ, or carried a superstructure of mudbrick, is not resolved, but the single gate in the southern wall appears to have been of stone construction, presumably with horizontal timbers in the wall faces to provide stability ${ }^{15}$. Equally lacking is firm evidence as to the original height of the four-metre wide wall. There are berms both in front and behind the wall on the rampart top. Neither inner nor outer sloping face of the rampart was provided with stone facing. There seems no good reason to modify the suggested drawn reconstructions of the wall and rampart made in the field by Michael Balance in 1957 and later by Summers, all published for the first time in $1993^{16}$.

\section{THE IRON AGE SETTLEMENT}

Situated on a small plateau below and to the south-west of the fortress, within the larger enclosure, is a settlement previously called the lower town (Fig. 6). On the 1:25,000 map this is marked as K1zfatma Harabesi although, strangely, the fortress is not specifically indicated (Fig. 2). Pottery sherds seen on the ground indicate that occupation was of the same period as the fortress. Using the historical imagery tool in Google Earth permits selection from a variety of imagery taken under different conditions at different times, as can be seen in Figure 8 where the details have almost as much clarity as the 1992 Balloon photos ${ }^{17}$. This settlement was not provided with strong defences, but it is possible to make out the narrow boundary wall and an entranceway on the north side while the remainder of the area, which is delimited by the edge of the bluff, seems not to have been protected by a wall or rampart. Immediately below this settlement at the northeast is a copious spring of good cool water, superior to the çeşme in Yaraşı ıillage.

\section{THE ENCLOSURE}

An area of about 634 hectares was enclosed by a stone wall almost exactly $11 \mathrm{~km}$ in length (Fig. 6) ${ }^{18}$. There are slight variations in the character of the walling in different stretches of its course that reflect topography, outcropping bedrock and immediately available building stone. Nevertheless, the entire construction appears to have been of a single build with no indications of alterations or repair. The greater part of its circuit is clearly visible except for the section that lies beneath the modern village. A single gateway has been recognised (discussed below). It can be presumed that the main point of entry lay beneath the village. On the eastern side of Yaraşlı village an Iron Age dam built across the stream was incorporated into the enclosure circuit (see below). Small portions or walling are occasionally incorporated into more recent and modern animal pens. The best-preserved sections of the wall are those following the ridges to Kurklar Tepe (Fig. 12) while walling on lower and more level ground, where there is better grazing for cattle as well as fields, has suffered greater damage (Fig. 13). The steep slopes of the Karacadag within the enclosure are today used for grazing. Traces of ancient terraces, perhaps for vines, can be seen on these slopes, but there no evidence as to their date. Agricultural fields are restricted to the northeast sector. This is the only area within the enclosure where there is sufficient soil cover to permit ploughing which even here appears to be a very recent phenomena (Fig. 6 where the lighter areas by $\mathrm{n}^{\circ} 11$ are freshly ploughed, some of the small and odd patches of this same ploughing are seen at top right in Fig. 8).

The walling, between 2.00 and $2.50 \mathrm{~m}$ in width, is constructed of andesite blocks none of which have been faced. Along some stretches, particularly those running along the ridges to Kurklar Tepe mountain peak, linear outcrops of bedrock have been incorporated into the wall. Nowhere is it preserved to a height in excess of $1.00 \mathrm{~m}$, and the amount of fallen stone indicates that the stonework never attained a very much greater height (Fig. 12-13). It seems impossible that it could have been carried higher in mudbrick because there is no hint of an eroded talus, nor of brickmaking pits. Furthermore, if a taller wall had been required it would very probably have taken less effort to raise it in stone than to manufacture and transport mudbrick. It is certainly possible, and perhaps likely, that there was some kind of timber palisade.

15) Horizontal timbers were set into the wall faces of the stone defences at Kerkenes, not far removed in time from the building of Cevre Kale. See Summers, in press a.

16) Summers 1992: fig. 2; fig 4c and d.

17) Compare Fig. 8 and Google Earth imagery available on line with photographs in Summers 1992 and Özgüner 2006.

18) Google Earth Pro calculates the length of the wall as $2 \mathrm{~m}$ short of $11 \mathrm{~km}$ and area within the circuit as digitized as 634 ha. Because of the steep slopes surface area would be greater. 


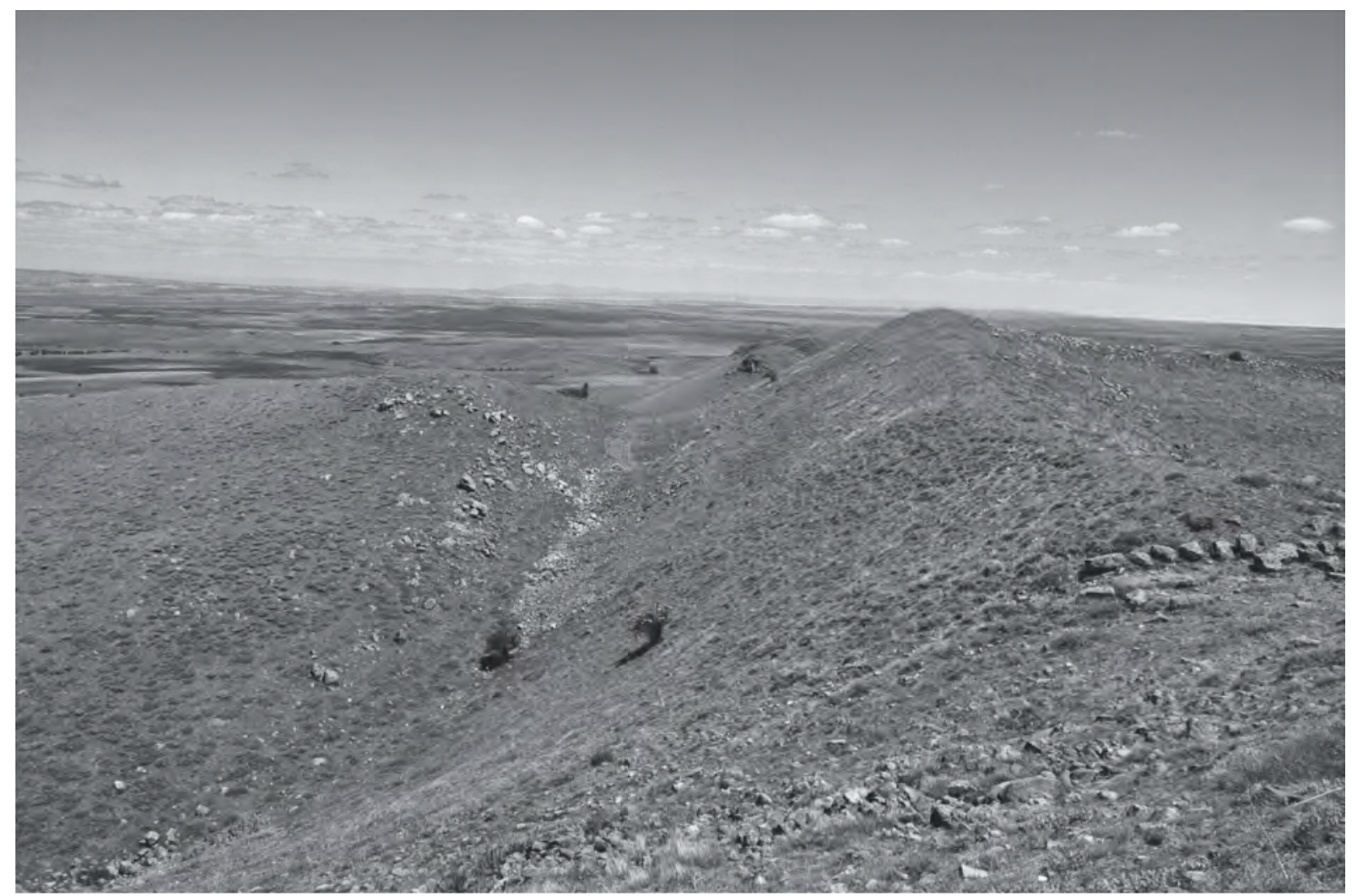

Fig. 11 : The rampart on the west side of the citadel with the ditch below. Stones at centre right marking the junction of the citadel to the main fortress rampart are perhaps a secondary feature.

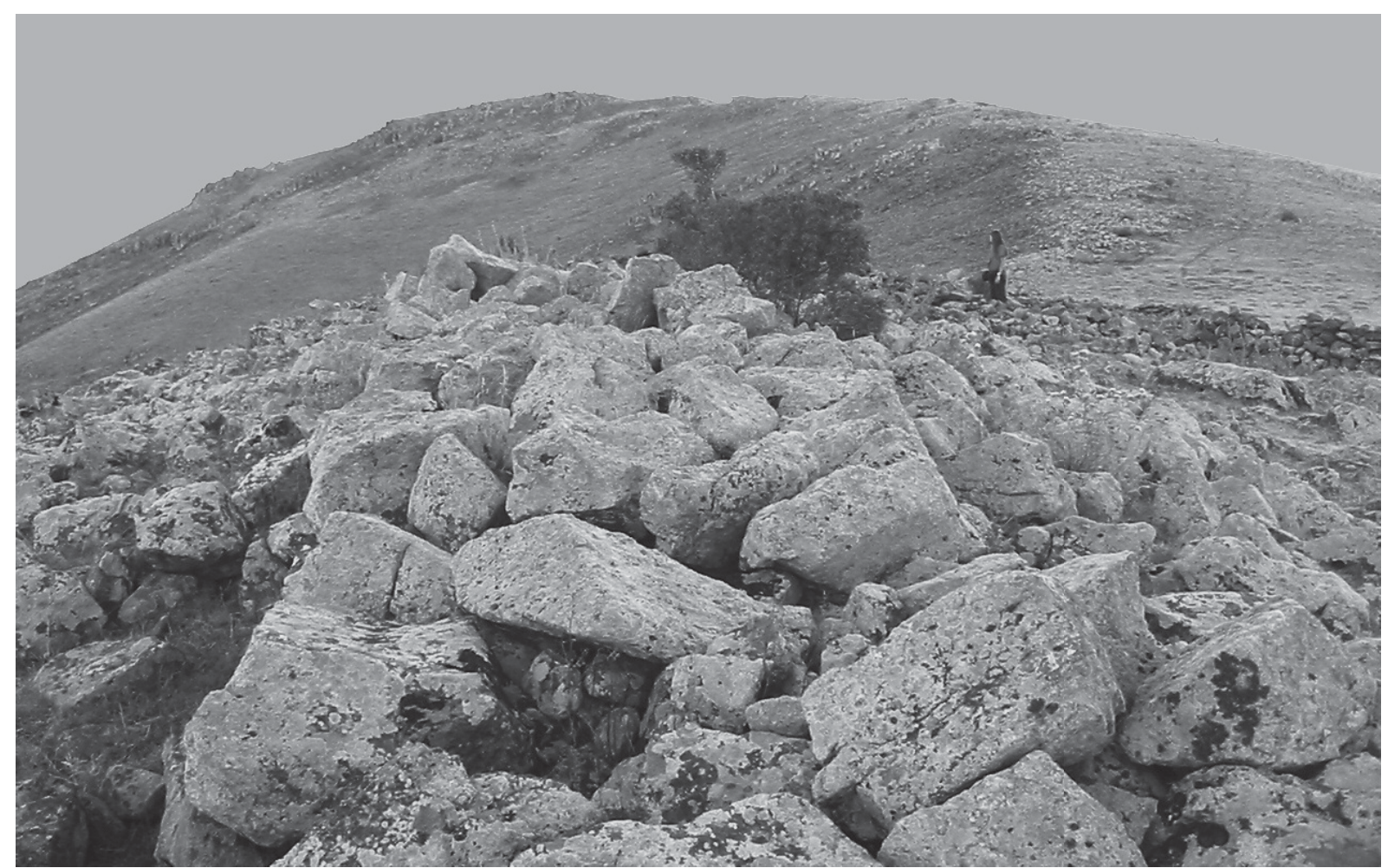

Fig. 12 : The enclosure wall on the northwest slope running up to Kırklar Tepe. 


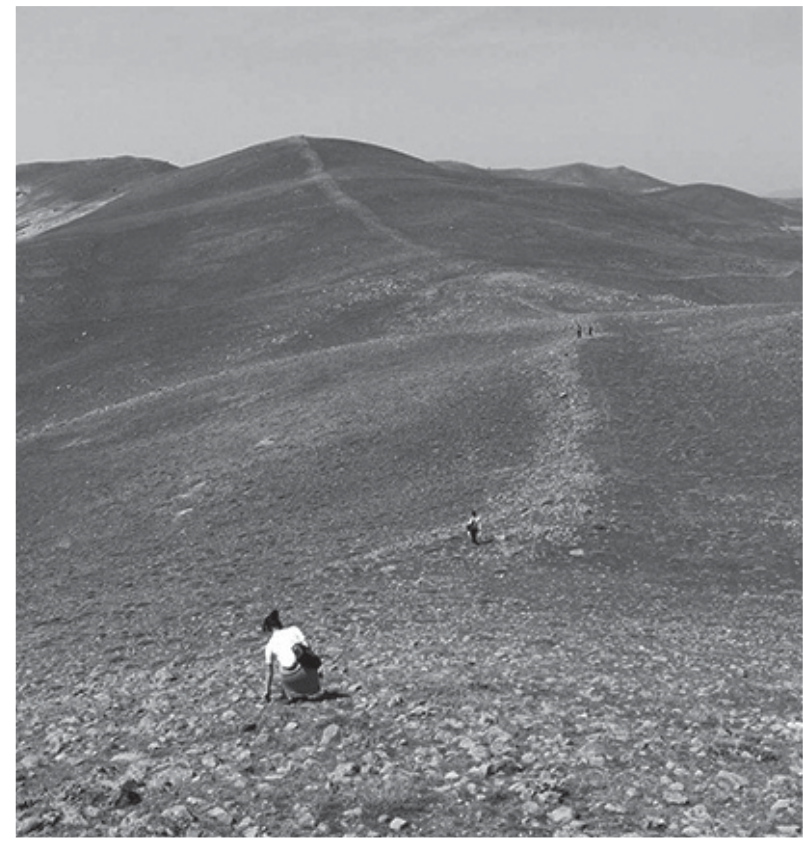

Fig. 13 : The enclosure wall looking eastwards along Köyüstü Sırtı to Karaoğlan.

There follows a description of the wall beginning on the west side of the village, ascending the ridge to Kırklar Tepe, the peak of the Karacadağ, before continuing down the ridge on the northern side where it swings round eastwards as far as the sole recognisable gate. Then comes the less well preserved section on more level ground that terminates at the dam on the east side of the village. Further details and a great number of illustrations can be found in Özgüner's thesis.

One of the most well-preserved sections is that running from the west side of the village, up along the ridge to Kirklar Tepe. Here some stretches incorporate bedrock outcrops while the built part comprised large unfaced stone blocks. It is this stretch of wall that, misidentified on stereo pairs of aerial photographs by cartographers, is shown as a track on the 1:25,000 map. The summit has been heavily impacted by later graves, plundering, and the erection of communication masts, with the result that it is not possible to determine whether or not there was some special feature associated with the wall at this point. Descending northwards and curving around to the east is a similar portion of the wall. The amount of fallen stone visible in Fig. 12 demonstrates that the original height was no more than twice what is now standing. Lower down, as the section of the ridge called Köyüstü Sirtı levels out, the line of the wall is cut by the modern track connecting
Yaraşlı and Dipdede villages (Fig. 13) before rising again to Karaoğlan Tepe. Along this entire stretch the wall is plainly seen although rarely preserved for more than a course above the modern surface. The only discernible gate is situated on the low ground between Karaoğlan Tepe and Hacidağ Tepe. While the position of this simple gate is clear, aerial images do not reveal sufficient detail for a plan to be drawn, in part because of the remains of later animal pens and recent disturbance. It is, however, apparent that there is a re-entrant with a more or less square open area in front that is flanked on the east by continuation of the enclosure wall, and there are also hints of an internal chamber or guardroom. A little way beyond the gate in a southeasterly direction traces of the wall become more ephemeral, although sufficient can be made out on the imagery and on the ground for it to be mapped with a reasonably high degree of confidence.

Where the wall descends from Hacidağ Tepe towards the village it comes to a watercourse that today is seasonal (Fig. 14-15). Here there was a dam across the stream. This dam is a continuation of the enclosure wall with the faces built of large unfaced stone blocks with a core of small stones. Four courses are extant in places, making for a preserved maximum height of about $2.00 \mathrm{~m}$. The inner wall face is distinctly battered, unlike any other part of the enclosure wall. On either side of this dam wall are banks of impervious clay that are preserved to a greater height than the walling. The outer, downstream, wall face is completely obscured by the outer bank or, where cut by the modern track, the blocks have been robbed out. Since the photographs were taken the village has encroached onto this area with the result that the dam has been further damaged if not destroyed. It will require a detailed topographic survey in order to calculate what volume of water could have been retained, but it is in any case obvious that construction of this dam required a considerable input of labour as well as expertise and organization. It seems that the purpose was to retain water inside the enclosure for some time following the end of snowmelt and spring rains. The pool that it created, which appears to have been some $4 \mathrm{~m}$ in depth where cut by the modern village track, would have watered animals well into the summer. In a normal year, however, it would surely have been dry by the end of summer. The implication, then, is that this water was for animals connected with the fortress, and therefore with military matters and campaigns. These would have included war horses and baggage animals. 


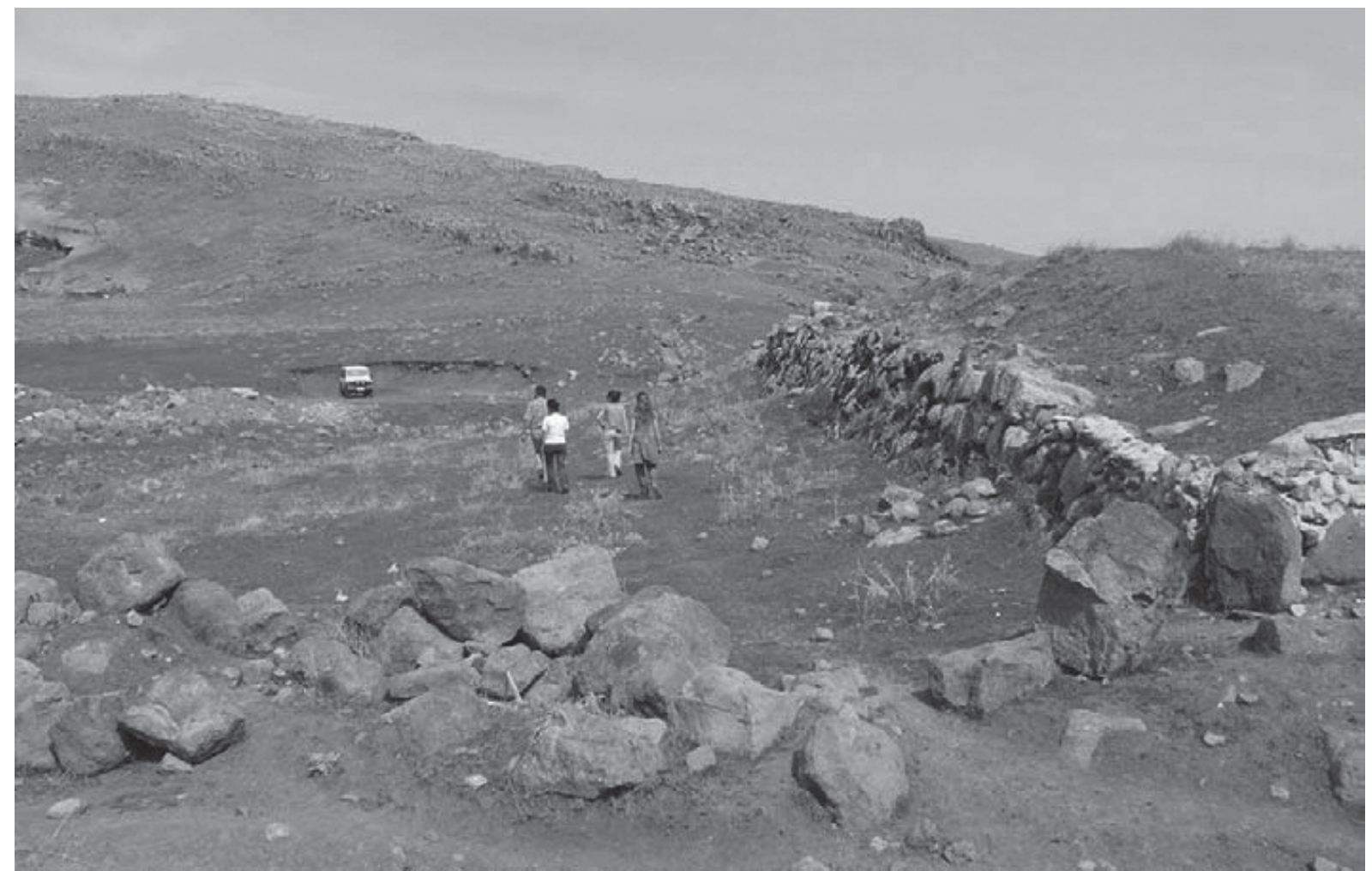

Fig. 14 : The inner battered face of the dam wall with the bank at right and a lower, inner, bank that the figures are traversing.

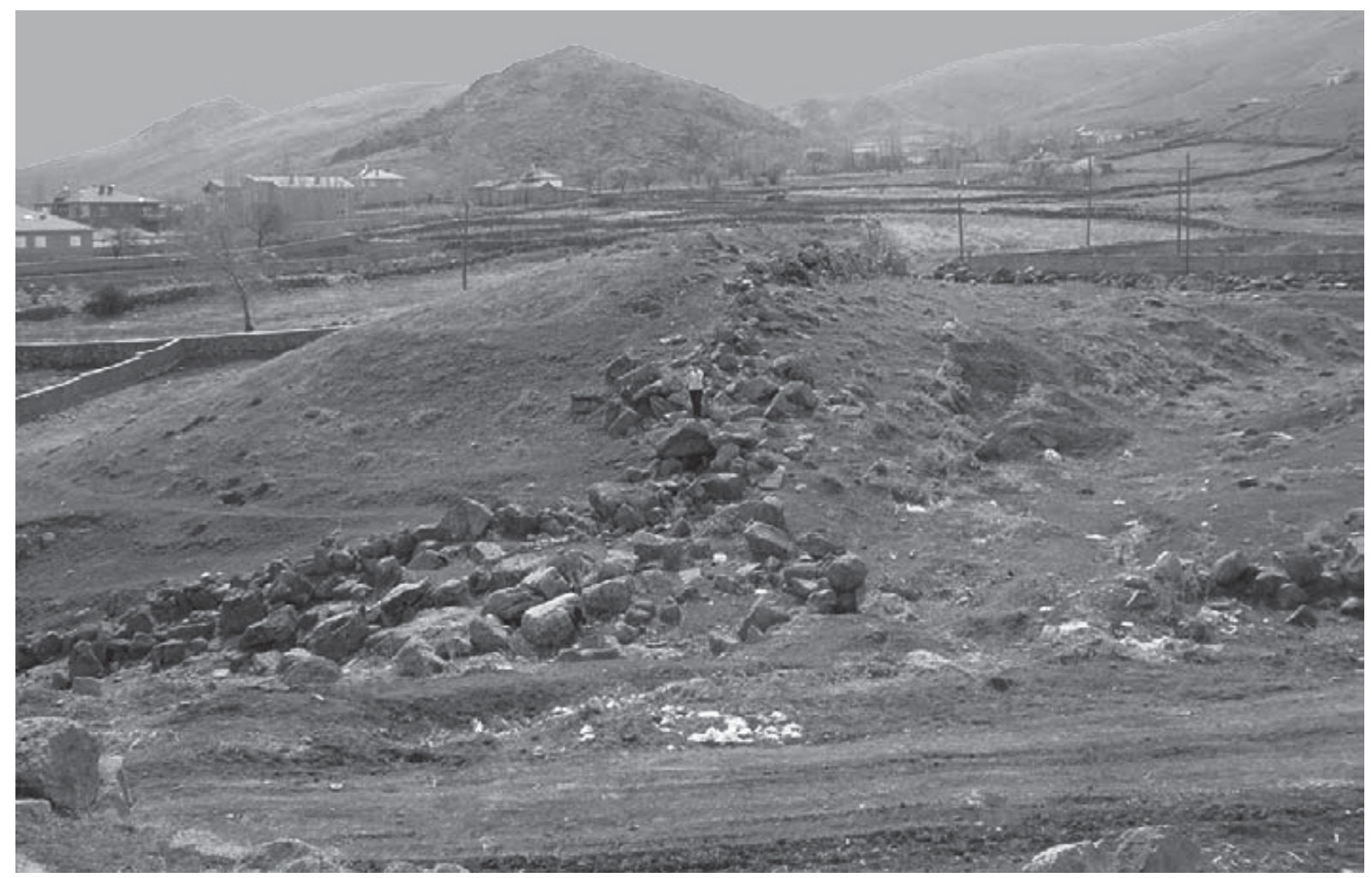

Fig. 15 : The dam from the east cut by the village road. 


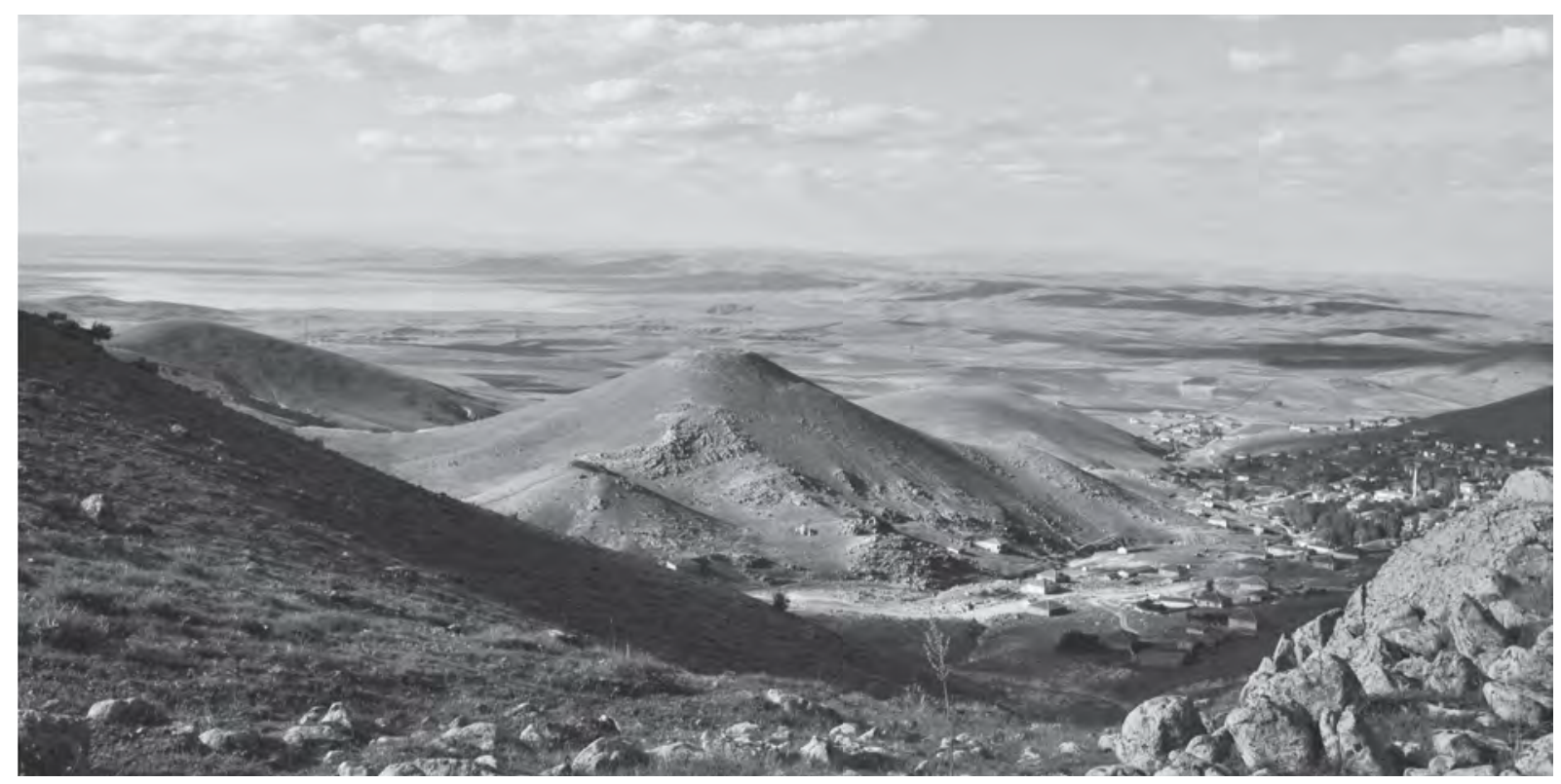

Fig. 16 : Kale Tepe with Dipdede village at right.

\section{THE SECOND MILLENNIUM SETTLEMENT}

On a visit to the site with colleagues and students in 2012 it was seen that fields on gently sloping land to the northeast of Çevre Kale had been recently ploughed. The plough-soil, which was deeper than had been expected, was seen to contain plentiful sherds of second millennium date. This element of the site extends from the base of steeper barren slope below the northeastern side of the fortress to the stream courses to the north and east. The extent is difficult to gauge from no more than Google Earth imagery and a cursory visit, but it possibly covers an area approaching 10 hectares. Here must have been the elusive source of the material containing sherds of much earlier pottery that was used for construction of the Iron Age fortress ramparts. The site resembles a flat settlement rather than a mound or höyük. Further study and proper survey is required before more can be understood. Published pottery from the secondary context of the fortress seems to belong entirely to the Old Hittite Kingdom ${ }^{19}$. Nothing has been noted anywhere on the site to suggest continuation of occupation into the Empire period. This has implications for the identification of second millennium site that it would be premature to discuss here.

\section{DATING OF THE FORTRESS}

The sole additional ceramic evidence for the date of the Çevre Kale fortress to that presented in 1993 is a single sherd of Lydian marbled ware that was observed on the fortress citadel. Since publication of that report, however, it has become possible to further refine the dating of the diagnostic sherds. The absence of typical Achaemenid bowls would seem to confirm what is reasonably clear on more general grounds that the site should be placed in the pre-Persian period. In general the ceramics, and particularly the fine black-on-red ware ${ }^{20}$ and the coarser painted sherds, including a different variety of black-on-red ${ }^{21}$, are probably not earlier than the later seventh century, and perhaps fall into the first half of the sixth.

19) Summers 1992: 204-05 with fig. 11.

20) Summers 1992: fig. $7 \mathrm{n}^{\circ} 1-8$

21) Summers 1992: fig. 8. See also Özgüner 2006, chapter 6 which draws together more comparanda. Since these studies were made it has become evident that the varieties of Phrygian Grey Ware with well-defined rims as well as finer vessels micaceous slips are of exactly the same period as the black-on-red wares. 


\section{COMPARANDA}

There are no close parallels for the fortress ramparts and circuit wall. This being said, they do fit into the genre of earlier Phrygian defences seen on the citadel mound at Gordion, and the later city wall at Kerkenes ${ }^{22}$. On the Anatolian Plateau the closest conceptual parallel for an artificial rampart that steeply slopes on both inner and outer faces are the walls and rampart protecting the southern side of the Hattusa, the second millennium Hittite capital. There, however, both construction techniques and materials are very different ${ }^{23}$. The Iron Age stone walls at Midas City, as well as fortifications of the same date at nearby settlements, are of very different type $^{24}$. For the neo-Hittite period the only defences on the central plateau that can be comprehensively described surround the exceptional mountaintop site of Göllüdağ where, not surprisingly, the solid stone circuit wall is not provided with ramparts ${ }^{25}$. Much larger in scale and built of different materials is the Colossal Lydian Structure that forms part of the defensive circuit at Sardis $^{26}$. At Çevre Kale too there are sloping ramparts topped by a wall, but on a very much reduced scale. One question to be addressed is whether these are a unique response to a particular and peculiar topography and geology on the slopes of the Karacadağ, or whether they are a pale imitation of Lydian defences at Sardis.

\section{DISCUSSION}

If, as seems probable, it can be accepted that the Çevre Kale fortress and the huge outer enclosure should be considered as separate elements of a single site it is necessary to consider what their function may have been. Perhaps it might then be worthwhile to ponder which polity might have been responsible for their design and construction and, furthermore, to address questions of historical geography.
It is obvious enough that Çevre Kale is a fortress rather than a walled town or city. In other words, it was primarily a military site rather than a settlement. The settlement outside the gate through the ramparts is clearly associated, both spatially and chronologically. It is tempting, therefore, to envisage this outer settlement as providing for needs of a military garrison inside. While not provided with strong defences this outer settlement did have a wall and gate on the northeast side, overlooking the road into Çevre Kale, which is indicative of order and control. Such a settlement associated with a fortress in the Roman period would have been a vicus, but at Iron Age Yaraşl1 it is impossible to know what the precise relationship would have been. Is it perhaps possible that this was a settlement of bonded or possibly deported people who constructed the fortress, enclosure and dam as well as providing for other needs of the garrison $^{27}$ ? There is every reason to think that the despotic Kings of Lydia deported peoples in longstanding Near Eastern fashion ${ }^{28}$. By the same token, without excavation it cannot be ascertained who in addition to troops might have resided within the ramparts. Supporting evidence for this interpretation of Çevre Kale as a fortress for a military garrison is the absence of architectural terracottas that are abundant at Gordion in this period as well as at Sardis, and not infrequent at sites in between ${ }^{29}$. The shallowness of archaeological deposits across the site would make it very unlikely that no trace of a tiled building would have been seen had one existed. Their absence at Çevre Kale might hint at function rather than chronology.

What, then, to make of the enclosure? The wall is impressive in its length, and notable for the restricted number of (discernible) entrances, but the great length would have been extremely difficult to man in the event of attack, while the wall itself would not have provided a particularly formidable obstacle to determined aggressors. It encloses steep and, until high summer, well-watered land on the

22) Voigt 2012; Summers, in press a.

23) The most obvious differences are the casemate wall and the plans of the city gates in the Hittite period. It has become clear in the last two decades that the walls of all Hittite town defences are of casemate construction. Nor is the Hittite state known to have built fortresses of this type.

24) Summers, in press b.

25) Schirmer 2002.

26) Cahill 2010.

27) We have in mind here the Urartian site of Ayanis on the north shore of Lake Van where inscriptions list the deported peoples who were forced to build the fortress for King Rusa II. These peoples dwelt in the undefended lower town at the foot of the fortress, see various contributions in Salvini and Çilingiroğlu (eds.) 2001; and Çilingiroğlu 2004.

28) Such deportation by Croesus might be what Herodotus (Book I.76) meant with regard to the people of Pteria, on which see the commentary by Christopher Tuplin (2004, especially pp. 239-240).

29) Summers 2006. 
western side while to the east of the fortress there is more soil cover and land suitable for agriculture. The enclosure is a demarcation of territory that controlled movement of people and animals, protecting grazing land on the slopes and fields on more level ground. Can these substantial resources have been solely for the garrison and its dependants?

Abandonment implies changes in the both geopolitical and the military situation. That there was no longer a need for a garrison might suggest that borders had changed. Civilian settlement, whether or not there was a hiatus in occupation, is probably to be sought below the modern village where, in contrast to the fortress, fresh water was reasonably plentiful.

One way, perhaps, of considering the site as a whole is to think of it as a mustering place for seasonal campaigns. Indeed, this is precisely what James Mellaart thought, although he argued for a Hittite date rather than the Iron Age one that has now been established. In this case a garrison would not only have performed military duties but would have overseen the production and storage of supplies ready for summer campaigns, while the mustering of troops, together with animals for both warfare and baggage trains, as well as arms and equipment, would have been facilitated. This begs the question of what power constructed and manned the fortress, and who might have been the enemies.

By the last quarter of the seventh century Midas the Great of Phrygia was dead and deified, the NeoHittite states of Tabal seem to have collapsed, and Lydia under its aggressively expansionist King Alyattes was in the ascendance. His successor, the
Lydian King Croesus, perhaps completed the subjugation of Phrygia. If the testimony of Herodotus retains any credence the border between Lydia and at least nominally the powerful Medes was the Halys River, the modern Kizılırmak ${ }^{30}$. More likely, it now seems, the local Anatolian power within the bend of the Halys was the kingdom of Pteria with its capital on the Kerkenes Dağ, a place that Croesus would eventually capture and thereby bring about his own demise ${ }^{31}$. The language of inscription and graffiti, evidence of cult, architecture and material culture at Kerkenes were Phrygian. To the south of the Halys and east of the Pilgrim's Road we have very little idea about what was happening in the first half of the sixth century. According to Herodotus there was a five-year war between Lydia and the Medes for control of what was to become Cappadocia. Much recent scholarship has downplayed or discounted the strengths and abilities of the Medes, perhaps too much so. But before the Persian invasion there were other actors as well, not the least of whom were the archaeologically enigmatic Cimmerians who even managed to sack Sardis. If the Halys was the border, then a fortress and mustering place just behind it, on relatively cool and well-watered slopes of the Karacadağ, a vantage point that permitted surveillance of westward routes to the north of the Salt Lake, would make considerable sense. The fall of Sardis and concomitant expansion of Persian rule as far as the Aegean would explain abandonment of a stronghold that was now far from any border.

N.P.Ö and G.D.S.

30) Herodotus I.74.

31) www.kerkenes.metu.edu.tr 


\section{REFERENCES CITED}

Anderson, J.G.C., 1899: "Exploration in Galatia cis Halym, Part II", Journal of Hellenic Studies 19: 52-134, 280-318, Pl IV (map).

Cahill, N., 2010: "Sardeis Şehri; The City of Sardis", in Cahill, N.D. (ed.), Lidyalılar ve Dünyalart. The Lydians and their World, Yap1 Kredi Yayınları, Istanbul: 75-105.

Crowfoot, J.W., 1899: "Exploration in Galatia cis Halym, Part I", Journal of Hellenic Studies 19: 34-51, p1. IV.

Çilingiroğlu, A., 2004: "How was an Urartian Fortress Built?", in Sagona, A. (ed.), A View from the Highlands: Archaeological Studies in Honour of Charles Burney, Peeters, Leuven: 205-231.

French, D.H., 1981: Roman Roads and Milestones of Asia Minor 1: The Pilgrim's Road., BAR Int. Ser. 105, Oxford.

Haldon, J. (ed.), 1990: Constantine Porphyrogenitus - Three Treatises on Imperial Military Expeditions, CFHB 28, Verlag der Österreichischen Akademie der Wissenschaften, Vienna.

Kurt, H., Asan, K. and Ruffet, G., 2008: "The Relationship Between Collision-related Calcalkaline, and Within Plate Alkaline Volcanism in the Karacadağ Area (Konya-Türkiye, Central Anatolia)", Chemie der Erde Geochemistry 68.2: 155-176.

Kuzucuoğlu, C., 2015: "The Rise and Fall of the Hittite State in Central Anatolia: How, When, Where, Did Climate Intervene?", in Beyer, D., Henry, O., and Tibet, A. (eds.), La Cappadoce méridionale de la préhistoire à la période byzantine, $3^{\text {emes }}$ Rencontres d'Archéologie de l'Iféa, IFEA, Istanbul: 17-41.

Mellaart, J., 1983: "Yaraşlı Hillfort. A Hittite Stronghold in Galatia?", in Boehmer, R.M. and Hauptmann. H. (eds.), Beiträge zur Altertumskunde Kleinasiens: Festschrift für Kurt Bittel, von Zabern, Mainz and Rhein, vol. 1: 345-348 and vol. 2: p1. $69^{\text {nos } 1-9 . ~}$

Mitchell, S., 1973: "Yaraşlı", in French, D.H. (ed.), Ankara 50, Ankara Turizmi, Eskieserleri ve Müzeleri Sevenler Derneği Yayınları 5, Ankara: 60-62.

- 1982: The Inscriptions of North Galatia (Regional Epigraphic Catalogues of Asia Minor II. The Ankara District), BAR Int. Ser. 135, Oxford.

- 1993: Anatolia: Land, Men, and Gods in Asia Minor, Clarendon Press: Oxford.

Özgüner N.P., 2006: Çevre Kale: Applications of Newly Developed Methods, Technology and Data for Understanding the Iron Age City in Yaraşl, MSc Thesis, Graduate School of Social Sciences, Middle East Technical University, Ankara.

http://etd.lib.metu.edu.tr/upload/12607164/index.pdf
Roosevelt, C.H., 2014: “'Mapping Site-Level Microtopography with Real-Time Kinematic Global Navigation Satellite Systems (RTK GNSS) and Unmanned Aerial Vehicle Photogrammetry (UAVP)", Open Archaeology 1: 29-53.

Roosevelt, C.H., Cobb, P., Moss, E., Olson, B.R. and Ünlüsoy, S., 2015: "Excavation is Destruction Digitization: Advances in Archaeological Practice", Journal of Field Archaeology 40: 325-346.

Salvini, M. and Çilingiroğlu, A., 2001: Ayanis I: ten years' excavations at Rusahinili Eiduru-Kai 1989-1998, Istituto per gli studi micenei ed egeo-anatolici CNR, Roma.

Schirmer, W., 2002: "Stadt, Palast, Tempel: Charakteristika Hethitischer Architektur im 2. und 1. Jahrtausend v. Chr". In the exhibition catalogue Die Hethiter und ihr Riech: Das Volk der 1000 Götter, Theiss, Stuttgart: 204-227.

Strobel, K., 2008: “A Hittite fortress on Çevre Kale, Yaraşlı? Some notes", in Taner, T., Tibet, A. and Konyar, E. (eds.), Muhibbe Darga Armă̆ant. Muhibbe Darga Festschrift, Sadberk Hanım Müzesi Yayınları, Istanbul: 451-456.

Summers, G.D., 1992: “An Aerial Survey of Çevre Kale, Yaraşlı”, Anatolian Studies 42: 179-206.

- 2006: "Architectural Terracottas in Greater Phrygia: Problems of Chronology and Distribution", in Avunç, B. (ed.), Hayat Erkanal'a Armağan: Kültürlerin Yansımast. Studies in Honor of Hayat Erkanal: Cultural Reflections, Homer Kitabevi, Istanbul: 684-688.

- in press a: Kerkenes Final Reports 1. Excavations at the Cappadocia Gate, OIP, Chicago.

- in press b: "Notes on Chronology in the Phrygian Highlands: Cultic Installations, Defences and Clamp Cuttings", Journal of Near Eastern Studies.

Tuplin, C.J., 2004: "Medes in Media, Mesopotamia, and Anatolia: Empire, Hegemony, Domination or Illusion?", Ancient West and East 3: 223-251.

Voigt, M.M., 2012: "The Unfinished Project of the Gordion Early Phrygian Destruction Level", in Rose, C.B., The Archaeology of Phrygian Gordion, Royal City of Midas, University of Pennsylvania Museum, Philadelphia: 67-99.

Weeden, M. and Ullmann, L.Z. (eds.), 2017: Hittite Landscape and Geography, Brill, Leiden. 